UK science

\section{Now you see it, now you don't}

A MUCH-needed present for British science (generally regarded as being on its uppers) was divided and praised last Tuesday morning - but taken away, at least partially, in the afternoon. The moral of this strange story is that Britain's mechanism for allocating budgets between ministries is in need of drastic overhaul.

At noon on Tuesday, Sir David Phillips, the chairman of the Advisory Board for the Research Councils (ABRC), which each year allocates monies to its member councils, was praising the "courageous" action of Secretary of State for Education and Science Sir Keith Joseph in raising new money for science in 1985-86 and subsequent years. (He had promised an effective $\$ 16$ million annually for the research councils by a reallocation of resources within his own cash-limited ministry, making well-off British parents pay a little more for their children's university education and giving this as a bonus to science.)

But by 3 p.m. the same day, Sir Keith was having to bow before a storm of protest in the House of Commons from what sometimes seems to be the only effective British political opposition, given the large Tory majority - the Tory back-benches. Research Council (MRC).
Back-benchers had reacted with horror at what was really a fairly moderate increase in parental contributions to student grants among better-off families (see below). Sir Keith hung on to his principles (there will be a commission on student funding), reduced the new burden on parents, and was partly bailed out by the Treasury. The result was some $£ 3$ million less than expected for ABRC next year (and f6 million less for the "equipment grant" of the University Grants Committee). It was a "very disappointing" result according to a spokesman for one of ABRC's member councils, the Medical

Science will, however, still get more than was promised before Sir Keith's grants saga began. The way the Department of Education and Science now explains the figures is this. Sir Keith's plan had been to eliminate the minimum student grant of $£ 205$ a year, to increase the parental maintenance contributions for family incomes above $£ 11,500$ and to impose tuition fees for incomes above $£ 20,000$. This would have released $£ 60$ million in a full year but only $£ 39$ million next (not a full year as the financial and academic years do not

\section{Students granted a reprieve}

SiR Keith Joseph's retraction of his proposal to make better-off parents contribute to their childrens' tuition fees means that individual parents will be up to $\mathbf{\Sigma 2 0}$ a year better off at an expense to the government of $£ 21$ million in England and Wales. To find the $£ 11$ million that the Treasury will not provide, Sir Keith has reduced by $£ 3$ million the proposed increase to the science budget, by $£ 6$ million the proposed $£ 10$ million increase in the universities' equipment grant and by $£ 2$ million the increased grants in the Professional and Industrial Commercial Updating Programme (PICKUP), adult education and the microelectronics programme.

An inquiry into the whole subject of students grants is to be set up by Sir Keith to avoid the same kind of embarrassing miscalculations as occurred last Wednesday. No date for the review has been set, nor is there any guarantee that it will be an independent inquiry, but it will include the controversial suggestion that loans be made to students for their tuition and living expenses. The National Union of Students (NUS) strongly opposes this idea, believing that it discriminates against students from poorer backgrounds and those studying for a degree that does not relate directly to a business or profession. The organization does, however, welcome the suggestion of a review; at present $\mathbf{4 6}$ per cent of students do not receive the full extent of the deemed parental contribution, and now that the minimum award of $\mathfrak{£ 2 0 5}$ a year has been abolished, many students will receive nothing unless their parents support their decision to gain a degree.

The Committee of Vice Chancellors and Principals (CVCP) hopes to be included in any review of the grant process. Tired of the government ignoring detailed annual reports on how much students need to live on, CVCP intends to set up its own inquiry to advise the government in any case. As the last review on the subject was in 1962, the need for a new inquiry is pressing. NUS would like to see the whole concept of parental contributions abolished; under the present system, a student is not considered independent until the age of 25 .

Just how the cuts in the science budget increases will be implemented is not yet clear. The Department of Education and Science is leaving the details to the boards concerned. This must be of small comfort to the University Grants Committee which meets tomorrow; originally it was to discuss how to distribute the extra $£ 10$ million awarded to it for equipment by Sir Keith, but now its task is to divide up the much smaller cake of $\$ 4$ million extra. Instead of being able to grant equipment money to three "broad areas" of science, it will now have to decide on one such area. There is a general condemnation of "robbing Peter to pay Paul", where either the students or the research programme in Britain will be the loser.

Maxine Clarke match). Sir Keith has now been forced to cancel the imposition of tuition fees. This loses his department $£ 21$ million next financial year. The Treasury has offered f10 million, leaving $\mathrm{f11}$ million to find within the department.

The effect on the research councils is a £3 million loss compared with expectations at noon on Tuesday. In the financial year 1985-86, ABRC was to have received $£ 571$ million (an increase on last year based on price indexation) plus a bonus from Sir Keith's grants plan of effectively $£ 14$ million (plus $£ 2$ million from a salaries adjustment). This bonus will be reduced to $£ 11$ million (plus the $£ 2$ million). An intended $£ 10$ million bonus on the UGC

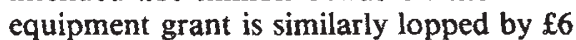
million, and $£ 2$ million is lost elsewhere.

The cut (and the bonus) may seem small, but on the original plans ABRC was to spend $£ 2.75$ million of the bonus on "restructuring" (effectively, pensions and redundancy). So the bonus amount for science is really falling from $£ 13.25$ million to $£ 10.25$ million, a large enough fraction that the horse trading over how to divide up the money among the research councils must begin again.

Discussions on this are taking place this week, when, unfortunately for the Science and Engineering Research Council (SERC), its chairman, Professor John Kingman, out of the country. Last week he had been describing his pleasure at the "enormously valuable" $£ 8$ million SERC was to have received. "Without this money we would have had to cut the number of the best (alpha) grant applications we could support to just 60 per cent of the applications", he said at noon last Tuesday, "but now we can raise it to 70 per cent".MRC equally was hoping to raise the same figure from the "disaster" of 53 per cent this year to "somewhere in the 60s".

Sir David Phillips has meanwhile been roundly condemning the almost entirely separate way in which the different departmental budgets are arrived at - so that the science budget of Department of Education and Science, for example, cannot benefit from savings, say, in the defence development budget (which accounts for a quarter of British research and development). The Department of Trade and Industry's research budget is also not "tradeable" with the ABRC sums. An infamous (if possibly apocryphal) case being quoted last week was the "heavy armoured vehicle" whose development in the Ministry of Defence cost hundreds of millions of pounds but whose doors would open only when the vehicle was level. The errors in the defence research and development budget alone, it was suggested, could bail out British basic and strat egic research. But such balancing - which should take place in the Treasury as Britain has no overall science minister - never takes place. It is time for a change, it is being said more and more loudly in the scientific corridors of power.

Robert Walgate 